\title{
A Study on Organizational Forms in Foreign Expansion of Korean Banks*
}

\author{
Jeong-Yoon CHOI ${ }^{1}$, So-Hyung KIM ${ }^{2}$
}

Received: April 04, 2020 Revised: April 27, 2020 Accepted: June 10, 2020

\begin{abstract}
So far, research into multinational bank' overseas expansion has focused on foreign direct investment in the financial services industry. However, this study focused its existing theories on multinational banks on decision-making related to the type of overseas advancement of local financial institutions. For research, four environmental factors were considered: the scale of foreign direct investment, the scope of financial services that can be provided according to the rules of the host country, the corporate tax rate of the host country, and the level of development of the host country's banking industry. Through Kotra, data on the total amount of claims from 2010 to 2014 and the regulatory status for the country's financial industries were obtained. Hypothesis are built around theories and survey factors and has been demonstrated through regression analysis. Results show that Korean financial institutions tend to expand as legally independent subsidiaries where the corporate tax rate of the host country is relatively low. Contrary to the previous studies based on the U.S. banking corporates, results show that Korean banks tend to expand in forms of branches to the host countries with high level of banking system development.
\end{abstract}

Keywords: Foreign Direct Investment, Korean Banks, Organizational Forms, Financial Services Industry

JEL Classification Code: M21, M48, N20, N25, P45

\section{Introduction}

Multinational corporations are actively expanding overseas and overseas expansion has become a necessity rather than a consideration. Therefore, corporations are examining environmental factors for overseas expansion to respond and prepare for them proactively. This study aimed to evaluate the impact of environmental factors of the country that the bank, one of the financial companies, tried to enter among many multinational corporations. The majority of previous studies on multinational banks have studied the factors influencing the banks' overseas

*This paper was extracted and developed from Jeong-Yoon Choi's Master's thesis (2014).

${ }^{1}$ First Author. Department of Business and Management, Seoul National University, Korea. Email: Jeongyoon. Choi@ gmail.com ${ }^{2}$ Corresponding Author. Assistant Professor, Department of Trade, Kyonngi University, Korea. Email: shkim2@kgu,.ac.kr

(c) Copyright: The Author(s)

This is an Open Access article distributed under the terms of the Creative Commons Attribution Non-Commercial License (http://Creativecommons.org/licenses/by-nc/4.0/) which permits unrestricted noncommercial use, distribution, and reproduction in any medium, provided the original work is properly cited. expansion itself. However, in terms of multinational banks' overseas expansion, the forms of the organization as well as the factors affecting the entry are important.

The financial industry, due to the nature of the industry, experiences relatively stricter and more specific regulations, imposed by government agencies, than other industries. Therefore, bank organizations may have different organizational forms depending on the business sectors and customer groups that a bank targets. Moreover, banks have different breadths of business and degrees of legal responsibility they can carry out depending on their organizational forms. It has important implications for multinational banks, which are entities entering foreign markets (Jeon, 2019; Esam, El, 2019). Additionally, it is meaningful for the policymakers of the government. This study aimed to review the previous studies related to the decision of the organizational forms in terms of multinational banks' overseas expansion.

Moreover, this study empirically analyzed whether the results of these studies could be applicable to Korean banks. This study targeted the cases of Korean commercial banks' overseas expansion in the form of subsidiary establishment or foreign direct investment of a branch, while these banks mainly acted 
as deposit banks. While determining the scope of the banking business in this study, South Korea had clear distinctions between banking, securities, and insurance industries.

The investment bank has been developed in the United States and other countries and has unique features. However, it exists in diverse financial industries in the form of an independent company. Therefore, this study excluded financial institutions that mainly operated securities businesses without the function of a commercial bank from the analysis.

\section{Literature Review}

\subsection{Organizational Forms of Overseas Banks}

Previous studies have discussed that corporations should choose organizational forms appropriate for their environments and multinational corporations should select organizational forms suitable for the environment of a country that they aim to enter. Particularly, Ghoshal and Nohria (1993) categorized the characteristics of the environment that could be faced by multinational corporations, matched each industry to a category, analyzed which environment they would face more likely, and emphasized which organizational form would be most appropriate for each industry.

Particularly, previous empirical studies analyzed the environmental factors affecting the decision of organizational forms during overseas expansion including risk, accessibility in the financial market of the country, and competition intensity while mainly focusing on four major forms (i.e., representative office, agency, branch, and subsidiary) out of seven organizational forms that can be used by a bank expanding overseas (Goldberg \& Saunders, 1981; Heinkel \& Levi, 1992; Cerutti, Dell'Ariccia, \& Martinez, 2007;Yi,2017).

Previous studies revealed that deciding the organizational form in banks' overseas expansion was important for the policy maker of the subject country that a bank tried to enter as well as the bank. From the viewpoint of multinational banks, it was directly related to whether the operation of a bank is a more centralized structure or a more dispersed structure, the scope of business in the subject country, and the possibility of responding to financial risks. From the viewpoint of policymakers, deciding the legal form of the multinational banks entering the country is an important issue because how foreign banks on the own soil or banks expanded to overseas based on the parent bank on the own soil cope with financial risks is directly related with the financial stability of the country (Robe, et al., 2011; Yi, 2017).

Multinational banks have a more centralized organizational form when they enter in the form of branch, rather than entering in the subsidiary form, which is an advantage. Especially, if it is a wholesale finance oriented bank focusing on corporate customers, this centralized structure with higher control can secure liquidity at a low cost in a short period of time, so it is better to seek overseas business in the form of branch. However, if a bank has a sales form that focused on retail financing rather than wholesale financing, branch may not be the right form.

If the business structure of a bank focuses on retail financing, the bank must consider the accessibility of the financial market of the country, which the bank aim to enter. In many cases, expanding business offices in the form of subsidiary, which is a legally independent entity from the parent corporation, is likely a method to increase the accessibility to the local financial market of the entering country. In such as situation, it is difficult for the central body to have control, but an overseas expansion organization is made as a corporation, according to the characteristics of subsidiary. However, the results of an existing study on bank organizational forms showed that one form would not solve all problems because there is a trade-off between efficiency and financial stability depending on which organization type is selected (Robe, et al., 2011).

\section{Research Methods and Materials}

\subsection{The Size of Foreign Direct Investment}

Previous studies have shown analysis results multiple times that, when banks entered a foreign country through foreign direct investment, they tended to go to a region where their existing customer companies entered (followthe-client motivation). This phenomenon occurred firstly because when a bank followed existing customers to a foreign region, where many existing customers had already established, while maintaining a strong relationship with them, the bank would have an advantage in relation to them over local banks in that region.

Secondly, if a bank does not follow an existing customer to a foreign country, the customer shall find a new financial partner in a newly entered country. As a result, the customer may break a relationship with an existing financial partner and form a new trading relationship with a competitor or a foreign bank in the motherland in order to make smooth communication with the motherland (Dunning, 1980; Goldberg \& Saunders, 1981; Gray \& Gray 1981; Ball \& Tschoegl, 1982; Nigh, \& Krishnan, 1986). If a bank follows a customer's foreign direct investment to a foreign country, the bank will try to run business in more diverse sectors, while influenced less by regulations (Miller \& Parkhe, 1998). As discussed earlier, the scope of business in the country depends on the organization type (subsidiary or branch). Since it is determined by national legislation, there is no absolute criterion for determining the scope of business for organizational forms (subsidiary and branch). 
Although the legal definition of the subsidiary is clearly different from that of the branch, some practical aspects of them are similar. For example, South Korea does not really legally differentiate the business activities of subsidiaries and those of branches for foreign multinational banks in South Korea, so it may not be possible to notice the difference. In addition to South Korea, branches and subsidiaries have almost equal independence in terms of financial liquidity in Argentina, Bolivia, Brazil, Chile, Ecuador, and India (Robe, et al., 2011). In some countries, there is no big practical difference between them, even though there are distinct legal differences between them. In most cases, a bank may offer different services, have a different scope of a business, and cope with risks differently depending on the legal form (subsidiary or branch).

Hypothesis 1: The amount of foreign direct investment by Korean corporations into a country in which the corporations have entered is positively related to the proportion of South Korean banks' subsidiary establishment in that country.

\subsection{Universal Banking Financial System}

When a company seeks to expand overseas, the company tries to expand into a country where the business environment, including its legislation, is less restrictive for the financial industry (Brimmer \& Dahl, 1975; Goldbergd \& Saunders, 1980; Rugman, 1981; Cho, 1986; Miller \& Parkhe, 1998). Specialized banking and universal banking mean the degree of regulation about the scope of business that banks can enjoy.

While the United States and Japan have a tradition of specialized banking, Germany is traditionally a representative country of universal banking. Countries have different views regarding the criteria of universal banking. In terms of business territory, it may mean to offer comprehensive financial services including deposits, loans, foreign exchange transactions, securities, investment management, and insurance.

On the other hand, from the perspective of the form of financial corporations, universal banking may mean that all works are done within a single company but, in a broad term, universal banking may be defined by including business through the relationship between a subsidiary and a holding company (Joya \& Lee, 2002; Kang \& Hwang, 2018).

As competition in the financial industry has been intensified, the banking business has not been able to find break through to increase profitability (Quaglia, 2010). As a result, banks have diversified into other areas of the financial industry, such as securities and insurance (Quaglia, 2010). As the universal banking has emerged as a response to improve profitability and cope with increased competition in the global financial market, the parent banks in South Korea, which aim to increase profits through overseas expansion, choose the form of subsidiary rather than that of branch when they enter a country with generous regulations on universal banking. It is expected that they would choose a form of subsidiary if they can carry out businesses in accordance with the legislation of the entering country, instead of South Korea legislation that still have legal barriers for combining different financial sectors such as banking, securities and insurance. A previous empirical study on the overseas expansion of American banks, while the US has traditionally adopted specialized banking, showed this correlation (Miller \& Parkhe, 1998).

Hypothesis 2: When it more tends to allow universal banking in a country in which the banks have entered, the proportion of South Korean banks' subsidiary establishment in that country will be higher.

\subsection{The Development of the Banking Industry in the Entering Country}

Previous studies have often assumed that there is a correlation between the level of development of the banking industry entering a country and the entry of multinational banks into the country, although different indicators were used. Cho (1986) analyzed based on the annual production of manufacturing in the country using an item of local banking market opportunity. Miller and Parkhe (1998) used the indicators of Demirguc-Kunt and Levine (1996) to observe total claim by deposit banks GDP and measured the development of the banking industry based on it.

Existing studies comparing subsidiaries and branches explained that subsidiaries, legally independent entities, had a wider range of the business that they could conduct in the subject country. Subsidiaries established overseas are legally responsible in their respective countries as entities independent of their parent company. On the other hand, branches are not recognized as legal entities independent of the parent company, and the legal responsibility for the branch becomes the legal responsibility of the parent company (Dell'Ariccia \& Marquez, 2010).

On the other hand, once a multinational bank enters an overseas market, it seeks to pursue profits through efficiency improvement by conducting business activities in the country (Fieleke 1977; Khoury 1979; Goldberg \& Saunders 1981; Cho, 1985, Miller \& Parkhe, 1998).

Moreover, the motivation is to use it as an opportunity to approach to the banking industry of the country (Fieleke, 1977; Khoury, 1979; Goldberg \& Saunders, 1981; Cho, 1985; Miller \& Parkhe, 1998). It is believed that, in this case, when the banking industry in the country in which a bank aims to enter is more developed, there would be more business elements that can be improved after entering the market of the country. 
Hypothesis 3: When the banking industry in the country in which it has entered is developed more, the proportion of South Korean banks' subsidiary establishment in that country will be higher.

\subsection{Taxation in the Entering Country}

When the corporate tax rate of the entering country is lower than that of the home country, corporations may select the form of a subsidiary to utilize the tax rate different advantageously.

Many of them pay taxes to the country accordingly and pay taxes to the mother country when transferring profits to the mother country. Previous studies on the banks in the United States assumed that such differences in tax rates would influence organizational decision-making in the overseas expansion (Scholes, Wolfson, Erickson, Maydew, \& Sheylin, 1992; Miller \& Parkhe, 1998; Cerutti, Dell'Ariccia $\&$ Martinez, 2007). It is believed that this method can be also applied to South Korean companies.

Hypothesis 4: When the corporate tax of the country in which it has entered is relatively higher, the proportion of South Korean banks' subsidiary establishment in that country will be lower.

\section{Data and Measurement}

KOTRA publishes a directory of the overseas expansion of South Korean companies covering every industry sector and all reported companies every other year. According to the KOTRA data, there are 27 countries that South Korean banks have entered and we can evaluate the status of them. Excluding the representational office type, there are 139, 131 , and 128 cases of overseas business in 2014, 2012, and 2010 , respectively, in the form of subsidiaries or branches.

This study excluded 7 countries where data on the total claims during the 2010-2014 survey period and regulation status about the financial industry in those countries are not available and examined 20 countries.

This study was based on the status of subsidiaries and branches reported in 2010, 2012, and 2014. The proportion of subsidiaries was calculated from the total subsidiaries and branches in one country in one year and it is considered as a single observation.

Cross-sectional time-series pooled regression method was used. The proportion of subsidiary (PROS) was considered as a dependent variable in the 4th data collected at the national level and it was estimated by FDI, UNIV, TC / GDP, and TAX, independent variables. FDI indicates the amount of foreign direct investment by South Korean companies into the country in USD and it was calculated by the unit of USD 1,000. UNIV means the degree of allowance of universal banking in the entered country and it ranges between 1 and 4 . A lower value means a higher allowance for universal banking. BI, measured by TC/GDP, refers to the total claim size by deposit banks compared to GDP of a specific country and it indicates the degree of development of a country's banking industry. TAX means the difference in corporate tax rates between South Korea and the country in which a bank enters. The estimation model is as follows.

$$
\operatorname{PROSi}=\beta 0+\beta 1 \mathrm{FDIi}+\beta 2 \mathrm{UNIVi}+\beta 3 \mathrm{BIi}+\beta 4 \mathrm{TAXi}+\varepsilon \mathrm{i}
$$

\subsection{Proportion of Subsidiaries in all FDI (PROS)}

It refers to the proportion of the subsidiary (subsidiary or branch) in the form of foreign direct investment operated in a specific country $i$ in a specific year. It is an indicator to see the preference of corporation type when entering a specific country (Miller \& Parkhe, 1998).

\subsection{Amount of Foreign Direct Investment (FDI)}

The annual investment statistics (1980-2014) provided by the Korea Export-Import Bank were used. The amount of FDI to a country from 2010 to 2014 was used.

\subsection{Degree of Allowing Universal Banking (UNIV)}

The standard regarding the degree of allowing universal banking varies depending on studies and the dataset classification criteria. Miller and Parkhe (1998) set it as a logistic dummy variable (1=allowing universal banking; $2=$ other cases). In their study, if a country allows a bank to work in commercial banking and securities activities at the same time, the county was considered to allow universal banking.

This study used the Banking Regulation Survey provided by the World Bank, which was previously used by Cerutti, Dell'Ariccia \& Martinez (2007) and Byun (2007). This index averages the values of four questions and it ranges from 1 to 4. It is closer to universal banking when the value is closer to 1 . Banking regulations survey was available only for 2008 and 2011, so that the observations in 2010 and those in 2012 and 2014 were constructed based on the 2008 survey and the 2011 survey, respectively.

\subsection{Development of Banking Industry (BI)}

Total claims GDP by deposit banks has been used as an indicator presenting the degree of development of the banking industry in a particular country in previous studies (Demirgüç-Kunt \& Levine, 1996; Miller \& Parkhe, 1998).

It was based on International Financial Statistics issued by the IMF. Total claims can be obtained from the reserves of deposit banks, claims on monetary authorities, claims on 
other resident sectors, and claims on nonresidents of deposit banks. GDP per country was based on World Bank data.

\subsection{Relative Corporate Tax Size (TAX)}

The corporate tax data for each country provided by KPMG was used. The difference from South Korea's corporate tax rate was calculated and the relative corporate tax rate was estimated.

\section{Results}

The equation,

$$
\mathrm{PROSi}=\beta 0+\beta 1 \mathrm{FDIi}+\beta 2 \mathrm{UNIVi}+\beta 3 \mathrm{BI}+\beta 4 \mathrm{TAX}+\varepsilon \mathrm{i}
$$

was estimated using 58 observations. The results showed that PROS increased when the amount of FDI was larger and UNIV was higher. Moreover, PROS was higher when TAX and BI were lower. The results supported Hypothesis 4 but Hypotheses 1 and 2 were not significantly supported. Hypothesis 3 was rejected. The correlation coefficients between independent variables are as follows.

The negative correlation between BI and UNIV was relatively strong. The results indicated that, in other words, a country with an advanced banking industry tended to allow banks to enjoy a wider range of businesses. However, we thought that it was not high enough to cause a collinearity issue.

FDI, UNIV, BI, and TAX were used to estimate the coefficients of the previously established linear model.

Table 1: Correlation Coefficient

\begin{tabular}{|l|l|l|c|c|c|c|}
\hline & \multicolumn{1}{|c|}{ average } & \multicolumn{1}{c|}{ std } & $\mathbf{1}$ & $\mathbf{2}$ & $\mathbf{3}$ & $\mathbf{4}$ \\
\hline FDI & 906054.789 & $1.32835 \mathrm{E} 6$ & 1.00 & & & \\
\hline UNIV & 2.3534 & .82190 & .209 & 1.00 & & \\
\hline BI & .039486 & 1.4270478 & .090 & -.552 & 1.00 & \\
\hline TAX & 3.7003 & 8.71205 & .174 & .270 & -.232 & 1.00 \\
\hline
\end{tabular}

Table 2: Estimation of Linear Model

\begin{tabular}{|l|c|c|c|}
\hline variable & $\boldsymbol{\beta}$ & Standard error & p-value \\
\hline (constant) & $856^{* *}$ & .187 & .000 \\
\hline FDI & $3.626 \mathrm{E}-8$ & .000 & .387 \\
\hline UNIV & -.177 & .080 & .031 \\
\hline $\mathrm{BI}$ & $-.120^{* *}$ & .045 & .010 \\
\hline TAX & $-.014^{*}$ & .006 & .028 \\
\hline
\end{tabular}

${ }^{*}$ Adjusted R2 0.133

PROSi $=\beta 0+\beta 1$ FDli $+\beta 2$ UNIVi $+\beta 3$ Bli $+\beta 4$ TAXi $+\varepsilon i$

$*$ : $p<0.05^{* *}: p<0.01$
The adjusted R2 value was 0.133, which was not high. It indicated that PROS would be explained by other variables that were not included in this study. FDI had a positive coefficient and the results meant that when the FDI of companies, which were the customers of mother corporations in South Korea, was larger, these banks also tried to provide financial services to these customers at a relatively wider range in foreign countries. The direction agreed with Hypothesis 1. However, the probability of this coefficient was 0.387 and it was difficult to consider that it was significant. It did not support Hypothesis 1. The coefficient of UNIV was -0.177 and it revealed that UNIV and PROS had opposite tendency. In other words, a country with fewer regulations had a higher PROS.

Although the directionality of this result agreed with Hypothesis 2, it was not significant $(p=0.31)$ and not able to accept Hypothesis 2.and Hypothesis 4 predicted that lower TAX would increase PROS. The coefficient of TAX was -0.014 and it was significant, so Hypothesis 4 was accepted.

Hypothesis 3 assumed that higher BI would lead higher PROS because banks would try to take full advantage of the convenience provided by the market such as efficiency enhancement. However, the results of this study showed opposite results $(\mathrm{p}=0.01)$.

This result was opposite to the results of the previous study using the same index for the overseas expansion of banks in the US (Miller \& Parkhe, 1998).

\subsection{Implication and Future Study}

This study targeted South Korean commercial banks conducting overseas business and analyzed the environmental factors affecting the organizational form of overseas operations of South Korean banks using observations made every other year over five years from 2010 to 2014 .

This study selected four representative environmental factors (FDI, UNIV, TAX, and BI) based on previous studies and evaluated hypotheses related to it using regression analysis.

The estimated coefficients did not accept Hypotheses 1 and 2 but accepted Hypothesis 4, the hypothesis on corporate tax in the country which banks entered in.

Statistical results regarding Hypothesis 3 on BI was contrary to the results of previous studies, conducted on the banks of the US. Hypothesis 1 was not supported by the result of empirical analysis and it could be because this study could not identify the overseas expansion of South Korean corporations focused on wholesale banking or retail banking.

Moreover, it would be possible that South Korean companies that entered the overseas market had a higher tendency to use other channels other than banks for necessary financial services. In the meantime, it would be possible that they were receiving services, which could be provided even if it is not a subsidiary, from the foreign branch offices of 
the banks, which they had transactions with, in the mother country.

Hypothesis 2 might not be accepted because it was difficult to quantitatively and accurately estimate the degree of UNIV. As mentioned earlier, universal banking has more than one definition, and it varies from country to country.

In addition, even if a bank is prohibited to do business in other sectors of the financial industry as a single company, there are countries where it is possible to operate multiple domains as a financial group through a holding company and subsidiary relationship. If legal specialized banking is not practically different much from narrow universal banking, it would be difficult to consider that these regulations would have enough power to explain PROS when selecting organizational form at the time of overseas expansion. Hypothesis 3 is based on the results of previous studies on the banks with US nationality.

Considering that the results of this were opposite to those of the previous study, it could be related to the international competitiveness of banks. If a company has a sufficient advantage when it enters overseas, it has the competence to be dominant in a country with the advanced financial industry and it has a motivation to enter in the form of the independent subsidiary.

However, South Korean banks are not strong in foreign countries and are relatively immature in the global financial market. Considering this, it is highly likely that it will be difficult for South Korean banks to gain competitiveness through direct competition in overseas local markets when entering into a country with an advanced banking industry.

Therefore, it can be presumed that the branch form can be more advantageous because the mother bank in the mother country has sufficient control over it and can provide necessary liquidity quickly when the situation in the market is not good.

\section{References}

Ball, C. A., \& Tschoegl, A. E. (1982). The decision to establish a foreign bank branch or subsidiary: an application of binary classification procedures. Journal of financial and Quantitative Analysis, 17(3), 411-424.

Brimmer, A. F., \& Dahl, F. R. (1975). Growth of American international banking: implications for public policy. Journal of Finance, 30(2), 341-363.

Cerutti, E., Dell'Ariccia, G., \& Martinez M.S. (2007). How banks go abroad: Branches or subsidiaries? Journal of Banking and Finance, 31(6), 1669-1692.

Cho, K. R. (1986). Determinants of Multinational Banks. Management International Review, 26(1), 10-23.

Dell' Ariccia, G., \& Marquez, R. (2010). Risk and the Corporate Structure of Banks. The Journal of Finance, 65(3), 1075-1096.

Demirgüç Kunt, A., \& Levine, R. (1996). Stock market development and financial intermediaries: stylized facts. The World Bank Economic Review, 10(2), 291-321.
Dunning, J. H. (1980). Towards an eclectic theory of international production: some empirical tests. Journal of International Business Studies, 11(1), 9-31.

Esam, El. (2019). The Impact of Financial Technology on Facilitating E-Government Services in Egypt. Journal of Distribution Science, 17(5), 51-59.

Ghoshal, S. \& Nohria, N. (1993). Horses for courses: Organizational forms for multinational corporations. Sloan Management Review, 34(1), 23-23.

Goldberg, L. G. \& Saunders, A. (1980). The causes of US bank expansion overseas: The case of Great Britain. Journal of Money, Credit and Banking, 12(4), 630-643.

Goldberg, L. G. \& Saunders, A. (1981). The determinants of foreign banking activity in the United States. Journal of Banking and Finance, 5(1), 17-32.

Gray, J. M. \& Gray, H. P. (1981). The multinational bank: A financial MNC? Journal of Banking and Finance, 5(1), 33-63.

Heinkel, R. L. \& Levi, M.D. (1992). The structure of international banking. Journal of International Money and Finance, 11(3), 251-272.

Jeon, J. H. (2019). Dynamic Spillover for the Economic Risk in Korea on Global Uncertainty. Journal of Distribution Science, 17(1), 11-19.

Kang, M. J.,.\& Hwang, H. J. (2018). The Effect of Customers Loyal to National Brand on Brand Launch Strategy. Journal of Distribution Science, 16(2), 1-6.

Khoury, S. J. (1979). International banking: a special look at foreign banks in the US. Journal of International Business Studies, 10(30), 36-52.

Miller, S. R. \& Parkhe, A. (1998). Patterns in the Expansion of U.S. Banks' Foreign Operations. Journal of International Business Studies. 29(2), 359-389.

Nigh, D. W., Cho, K. R., \& Krishnan, S. (1986). The role of location-related factors in US banking involvement abroad: an empirical examination. Journal of International Business Studies, 17(3), 59-72.

Quaglia, L. (2010). Governing financial services in the European Union: banking, securities and post-trading. Routledge.

Robe, I. O., Fiechter, j., Surti, J., Hsu, M., Santos, A. O., \& llyna, A. (2011). Subsidiaries and Branches: Does One Size Fit All?. International Monetiar Fund.

Rugman, A. M. (1981). Inside the Multinationals: The economics of internal markets, Columbia University Press. New York.

Scholes, M. S., Wolfson, M. A., Erickson, M., Maydew, E., \& Sheylin, T. (1992). Taxes and business strategy: A planning approach, Prentice Hall. Englewood Cliffs. New Jersey.

Waheed, A. \& Mathur, I. (1995). Wealth effects of foreign expansion by US banks. Journal of Banking and Finance, 19(5), 823-842.

Yi, H. T. (2017). The Effect of Composite Incompatibility on Relationship Commitment and Performances in Franchiser-Franchisee Relationship, Journal of Distribution Science, 15(2), 91-100. 